\title{
URBAN PLANNING PERSPECTIVES OF THE POTENTIAL OF RESORT DEVELOPMENT IN THE SERGEEVKA SETTLEMENT WITH TRAFFIC IMPROVEMENT
}

Scientific paper

(Received: 12 September 2019; accepted: 10 June 2020)

\author{
Nataliya Belskaya \\ Odessa State Academy of Civil Engineering and Architecture, senior lecturer \\ Marina Kramarenko \\ Odessa State Academy of Civil Engineering and Architecture, senior lecturer, PhD \\ Corresponding author: marinakramalex@gmail.com
}

\begin{abstract}
The Sergeevka resort is the largest climatic-balneal-mud resort in the south of Odessa region. This article presents an overview of the current state of the resort and an analysis of its transport-planning scheme. In addition, suggestions on the resort's availability and improvement of its functioning are provided through reconstruction of the resort's external (in particular with Odessa) and internal transport links. Based on the city-planning analysis of the existing access roads to the resort and within its territory, the study presents a concept of the organization of the transport scheme. Its basic arrangements will provide the opportunity for the development of the resort by contributing to the influx of vacationers and investments and creation of new workplaces.
\end{abstract}

Keywords: health resort; urban planning; transport connections; Sergeevka; tourism strategy. 


\section{INTRODUCTION}

The coastal territories of southern Odessa attract considerable interest for the development of resorts and recreational centers. Many tourism types, such as health-resort, spa, marine, water-sports, ecological, ethnohistorical, religious, festival, and art tourism are developed here owing to the presence of its steppe climate, sea beaches, and coastal salt lakes that are rich in medicinal brines and peloids.

Sergeevka is the largest seaside climatic-balneal-mud resort in the south of Odessa region, and no large industrial enterprises exist within the radius of $60 \mathrm{~km}$. The resort covers an area of $640 \mathrm{ha}$, with 82 ha occupied by green spaces. Initially, the Sergeeva settlement specialized in services such as sanatoriums, spas, and medical institutions. In addition, it dealt with the manufacture of medical products and was intensively designed and built up as a spa-medical cluster until the 1980s. Owing to the lack of systemic state management of coastal marine zones, the area's subsequent development slowed down and buildings were left unfinished, with unresolved issues of employment. Today, the resort is the most valuable resource of the Odessa region but operates below its potential and remains underfunded, with inadequate infrastructure and lack of clear development plans. In 2017, the "Development Strategy of Tourism and Resorts until 2026" was adopted; it gives hope for the creation of mechanisms to promote the development of Odessa's resorts [1].

\section{LITERATURE ANALYSIS AND PROBLEM FORMULATION}

During the initiative of the state administration of the Belgorod-Dniester region in 2016 and 2017, scientificpractical conferences on "urban planning and management of coastal territories" were organized with emphasis on the Sergeevka settlement. Specialists from several research foundations such as "Ukrainian Research Institute of Medical Rehabilitation and Balneology of the Ministry of Health of Ukraine" and Odessa State Academy of Civil Engineering and Architecture participated. They answered questions on the regional recreational system of the development Odessa region, the project approach to the development of coastal territories, the criteria for developing the compositional scheme of the Shabolat estuary coast, and others [2].

The theoretical basis for the research on the architectural design problems of the resort facilities have been presented by several researchers. In particular, the town-planning organization of resorts was investigated by Kaplan and lonov [3], Panchenko [4], and Stauskas [5]. In addition, the architectural formation problems of sanatoriums, health-improving institutions, and public buildings in resorts have been studied by Belska [6] and Tkachenko [7]. Moreover, Kaplan [3] presented the transport and pedestrian connections in resorts by highlighting the new state building instructions of Ukraine in 2018, and Sidorova [8] presented the principles of functional planning organization of the coastal strip of coastal resorts.

Karasyova [9] discussed the features of the accommodation and architectural planning decisions of hotel complexes with small capacities in nature-reserve areas, as well as techniques for the three-dimensional spatial organization based on the principles of environmental friendliness, aesthetics, and contactability. The following recommendations are also useful to preserve resort areas such as Sergeevka.

Although these scientific investigations have great theoretical and practical importance, a methodological approach of solving the problem of the potential recommendable development of Sergeevka resort and the improvement of its transport links has not been identified yet. Accordingly, this study considered the growth of the social and rehabilitation role of medical and recreational activities in resorts and the high potential of the resort, which is based on the following factors: exceptional natural and climatic resources, the availability of functioning sanatorium and resort institutions with a medical-rehabilitation profile, professionally trained personnel interested in new workplaces, and economic importance evidenced by the Law of Ukraine (2000) [10].

\section{PURPOSE AND OBJECTIVES OF THE STUDY}

The purpose of this article is to provide an overview of the characteristics of the Sergeevka resort's current state and develop a concept for renovating the resort's transport accessibility. To achieve this goal, the following research objectives were identified:

1. Analysis of the status and development opportunities of the treatment-rehabilitation complex. 
2. Assessment of the potential of the tourism types and directions in the area of the Sergeevka resort.

3. Urban analysis of the territory of the Sergeevka resort.

4. The concept of reorganizing transport access schemes to develop the resort potential and attract vacationers and investments.

\section{BASIC THEORY}

\subsection{Characteristics of the Sergeevka resort}

Sergeevka is a settlement located $19 \mathrm{~km}$ from the Shabo railway station and $18 \mathrm{~km}$ southwest of BelgorodDniester city. The resort is formed on the shores of the Budak (Shabolat) coastal salt lake. The main natural healing factors of Sergeevka are its climate (the combination of warm steppe with sea air is a unique healing factor); the sulfide silt mud of the Budak estuary is used for mud therapy. In addition, the waters of the coastal salt lake are used for the preparation of various mineral baths and the mineral waters of the wells of the resort are used for the complex treatment of diseases affecting the internal organs. The treatment of patients with diseases of the musculoskeletal system, breathing (non-tuberculosis), nervous system, gynecological diseases, and skin diseases of both children and adults are provided at Sergeevka. The main area of activity to the local population is provided by enterprises and companies in the recreational fields. The climate is determined by the Black Sea, forested areas, and steppe expanses, which approach the resort from the north and is transitional from the sea to continent. The area possesses acacias, ornamental shrubs, and an extensive park on its territory. Its winter is mild with unstable snow cover (average temperature: $-2^{\circ} \mathrm{C}$ ). The summers are warm and dry with prevalence of slightly cloudy weather (average temperature: $-22^{\circ} \mathrm{C}$ ). These conditions allow the resort to be functional all yearround.

The Budak estuary (length, $17 \mathrm{~km}$; width, $1.5 \mathrm{~km}$; depth, $0.2-1 \mathrm{~m}$ ) is separated from the Black Sea by a narrow (up to $150 \mathrm{~m}$ ) sandy embankment, which is a beautiful beach used for thalassotherapy. In 1972, the pedestriantransport bridge that is more than $1-\mathrm{km}$ long was put into operation over the estuary, which connects the mainland with a sea spit. [11] (Figures 1 and 2):

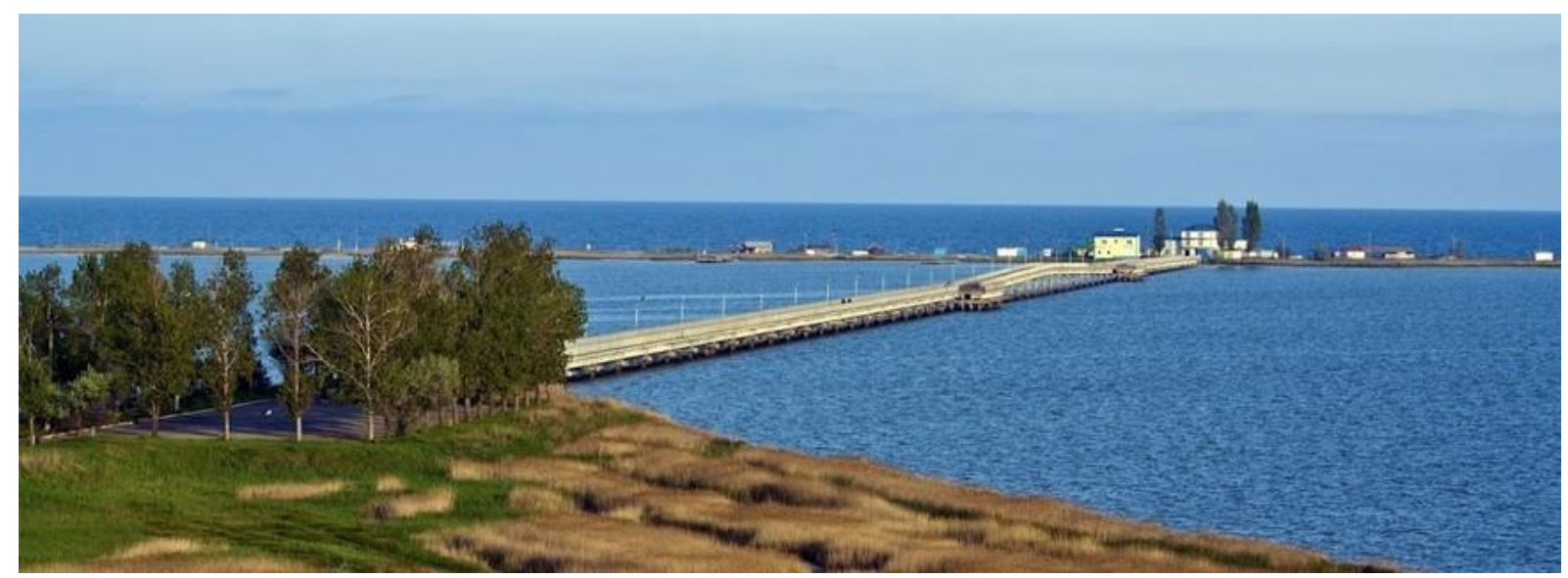

Figure 1 Pedestrian-transport bridge over the Budak estuary [12] 


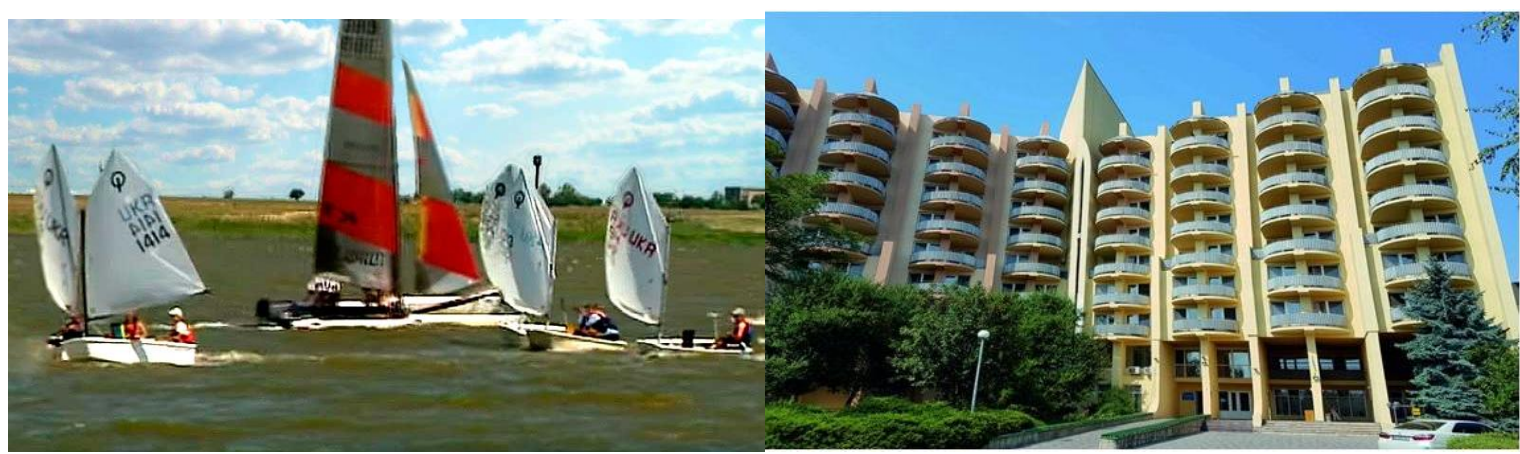

Figure 2 The Budak estuary [12]

Figure 3 Sanatorium Horizon [13]

In addition to the medical and rehabilitation centers, tourism directions and types, such as historical, sports, ethnic, religious, and festival-based tourisms, are attractive in Sergeevka.

The Sergeevka resort was founded in 1940 and was built up intensively in the second half of the 20th century. An abrupt change in the formation as well as social and economic priorities at the turn of the 20th to 21st centuries led to a stoppage in the development of the resort industry. At this moment, Sergeevka, similar to other resorts located to the south of Odessa city (Gribovka, Zatoka, Karolino-Bugaz, etc.), was built up spontaneously without urban-planning substantiation. The general state of the enterprises of the resort industry in Sergeevka requires modernization and reorganization. The existing developments of health resorts along with accommodation and meals, offer spa and medical services; however, their material and technical bases are outdated, thus negatively affecting their load and functioning. In general, the current state of the resort's development, requires extensive changes and does not meet modern requirements [14].

\subsection{Urban planning analysis of the Sergeevka resort territory}

According to Figure 4, detailed topographic map of the surroundings of Odessa from 1970 to 1980 show the roads that were laid along the boundaries of land plots and that connected the settlement of Sergeevka with Belgorod-Dniester. The railway, built in 1916, passed from Odessa to Belgorod-Dniester, as the main administrative and production center of the Belgorod-Dniester region. Sergeevka was considered to be the main resort for the inhabitants and workers of Belgorod-Dniester.

The analysis revealed the lack of a master plan for Sergeevka with respect to the current state of the settlement and prospects for its development. The modern overview of the map of the Odessa region shows only the boundaries of the Sergeevka settlement, highway, and main road of T1610 (Figures 5 and 6 ).

A study of the resort's potential shows that 18 recreational facilities are currently functioning on Sergeevka's territory. These include 6 sanatoriums (such as the Lazo sanatorium for 500 people with a spa clinic, the Patria with capacity of 355 people, the Horizon (Figure 3), and many others), about 7 children's health camps and resorts, recreation and retreat centers, health centers, hotels, campsites, mud baths and holiday homes. 


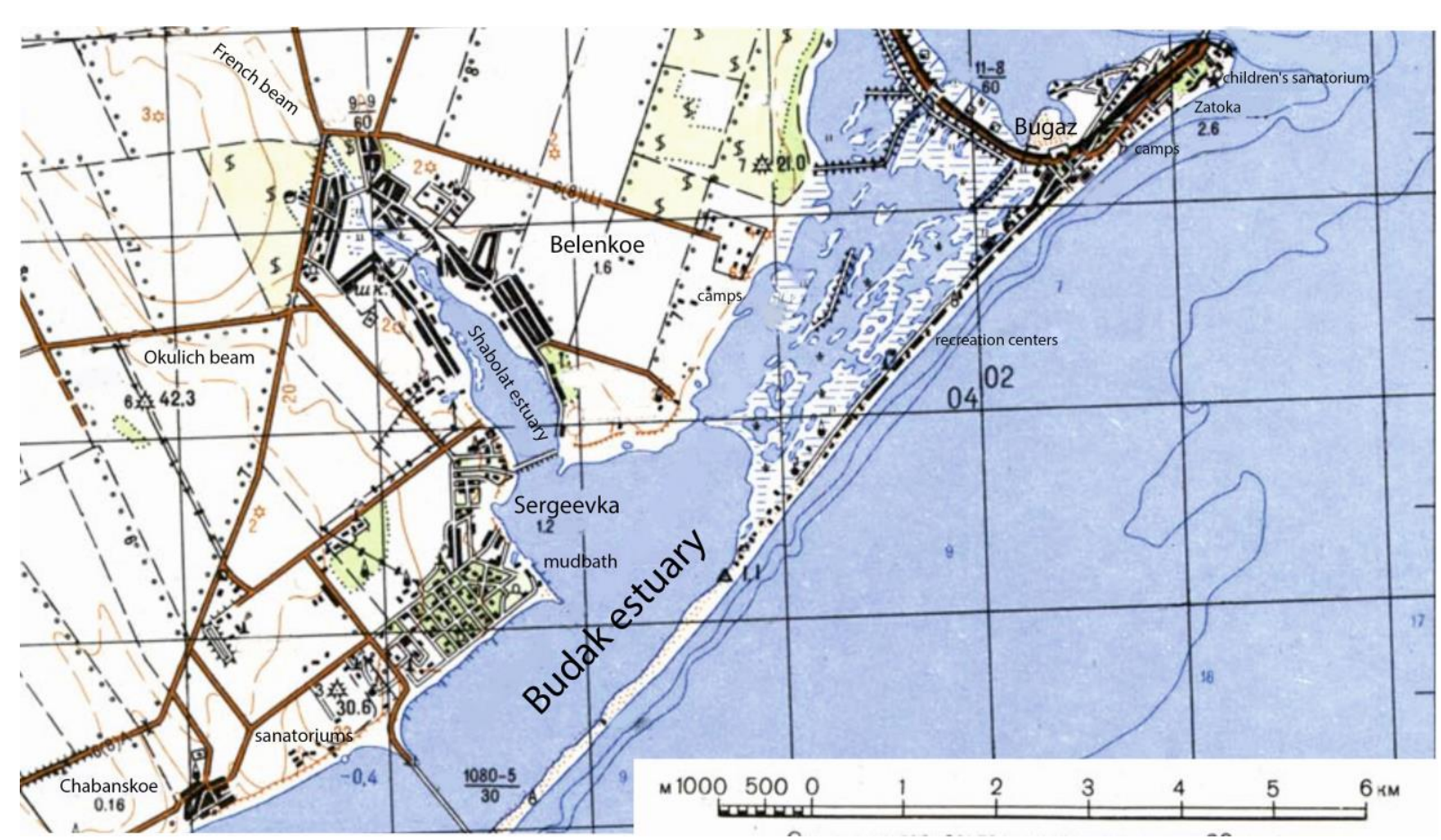

Figure 4 Fragment of detailed topographic map of the surroundings of Odessa 1970-1980 [15]

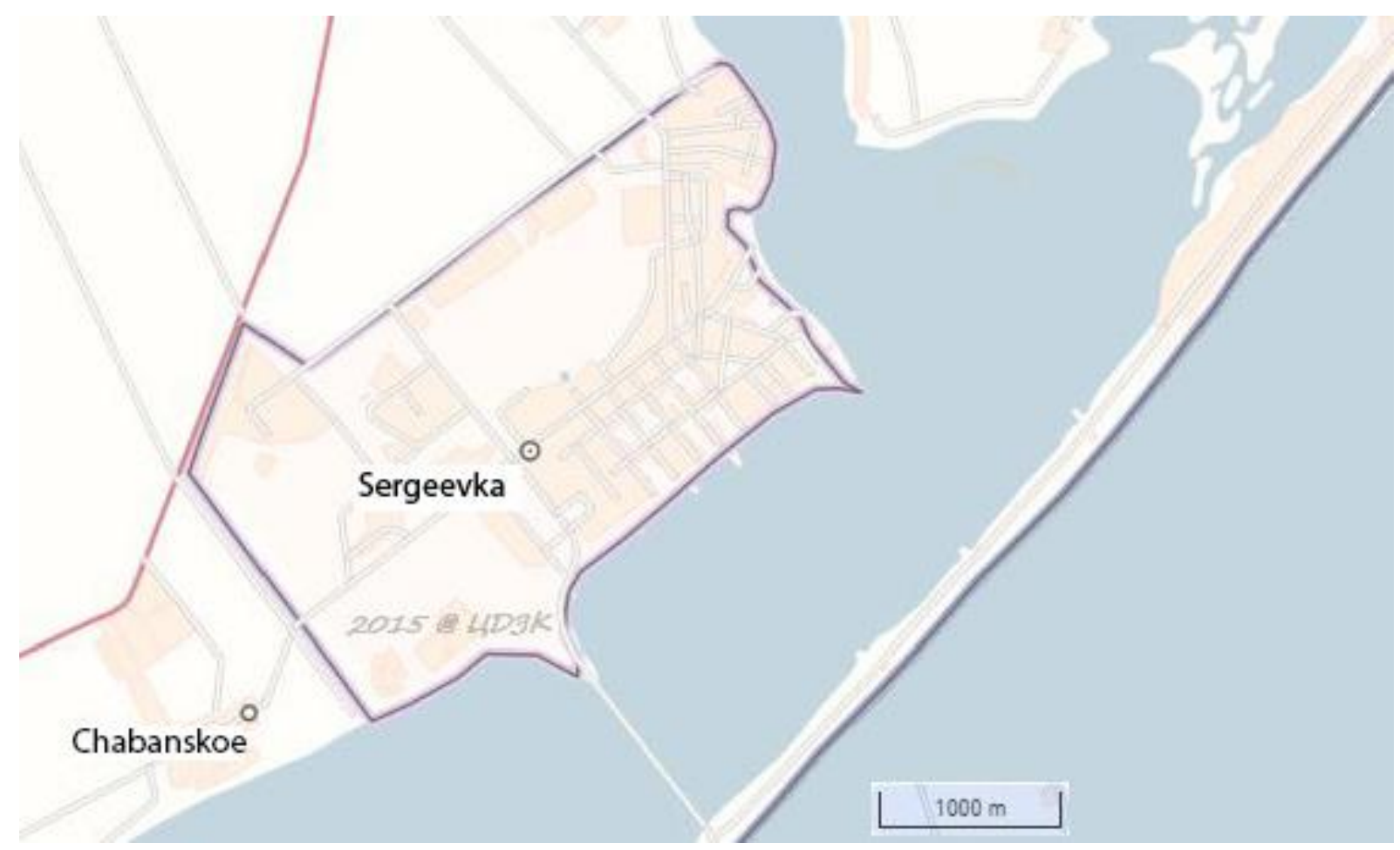

Figure 5 Fragment of the map showing the surroundings of Odessa with the Sergeevka settlement, 2015 [16]

The plans also include the construction of the largest resort and recreation complex in Ukraine, the Lazurny water park, which can accomodate 4000 visits per day with an area of 8 he, located on the spit between the Budak estuary and the sea [17]. Despite the presence of a health-improving base, field-based research has shown the lack of infrastructure in the resort town: the primary problems that impede the development of Odessa's south 
region, in particular the Sergeevka resort, are the existing outdated transport links; the absence of the resolved public promenade; and other recreational areas with catering, sport facilities, and other attractions.

Analysis of the current vacationers of the resort showed that the most of them come from Odessa and other Ukrainian regions, and their move to the resort is quite tiring. That is, the railway still connects Odessa with Belgorod - Dniester ( $2.5 \mathrm{~h}$ of travel), after which the vacationers must transfer via bus (1 $\mathrm{h}$ of travel). An alternative route to the train is a scheduled minibus (1.5-2 h) with minimal comfort and high speed for the current road condition. Both the internal and external road transports are the main routes through the town. In addition, the state of these roads, for example, between the Sergeevka and Shabo settlements in the vast majority of sections, can be described as "off-road," and the roads that connect Odessa city with the Sergeevka resort require re-routing, reorganization, and expansion, especially in problematic areas. Moreover, the arrangement of sidewalks and bicycle paths is required for safe and comfortable use as well as greater traffic passing ability.

The water transport, previously functioning in the mode of intercity connections during navigation periods and characterized by its attractiveness to tourists, has stopped functioning after the collapse of the USSR. Presently, in the peak season of the resort, only cutters and boats run along the estuary for delivering vacationers and local residents to the sea spit.

This area does not have air transport.

The analysis of resorts throughout Russia and other post-socialist states could allow the determination of the general tendencies of coastal resort development. First -, the planning and organization of modern resorts differ in multifunctionality (the presence of various functional zones, such as - resort, sports, tourist, recreational, residential, business and industrial zones). Multifunctionality has been implemented in resorts, such as Sochi (Russia), Eforie (Romania) and Bansko (Bulgaria). Another trend of coastal-resort planning involves their integration into a single spatial structure of the town; this ensures "sustainable" development of territories in the future. These principles should be used during reorganization of the Sergeevka resort.

The analyses of the planning and operation of resorts in Ukraine (Kuyalnik, Morshyn and Truskavets) and a number of foreign resorts in Russia (Sochi and Matsesta), Czech Republic (Karlovy Vary and Teplice), Germany (Baden-Baden), and France (Vichy) show that the level of infrastructure and provision of urban amenities in Sergeevka does not meet the current European and world standards. This reduces the tourist attraction of the Sergeevka resort.

To solve various aspects of creating a network of territories by considering the recreational potential and the developmental prospects of resorts, recreation zones, tourism, etc., a comprehensive research must be conducted along with pre-designing and planning work at the state, regional and local levels.

A system of transport links, designed to provide comfortable access to the resort, should be developed using both existing and newly designed communications, including external roads (for connecting the resort with other settlements), distribution roads (for communication between functional areas in the resort), internal recreational roads (for the operation of the corresponding facilities), excursion and tourist service roads, and mode roads (for vehicles that serve the resort area, scientific sector, and household needs) [4]. Interviews of the residents and vacationers as well as on-site investigations revealed that the existing system of transport connections in the Sergeevka resort is underdeveloped and does not correspond to the resort's possible throughput. Thus, the following are the actual problems hindering proper development of the Sergeevka resort potential. There is a lack of adequate resort development programs adopted on competitive terms, considering the basic needs of the population of the town for education, cultural, scientific and production activities, along the development of the spa component. In addition, the problems of the resort's transport links with the "metropolis" (within the framework of the general transport problems of the metropolitan area) are unresolved, both in terms of variability (road, rail and water transport) and in terms of length, route, and quality of existing transport links [6].

\section{CONCEPTS AND PROMISING DIRECTIONS IN REVEALING THE POTENTIAL OF THE RESORT}

\section{1 Basic principles of organizing transport communications at the resort}

The planning and development of the resorts and recreation areas should ensure the creation of the most favorable conditions for patients and vacationers, as well as for work, life, and recreation of the local population. The network of streets, roads and driveways should meet the needs of the resort and recreation area for all types

Belskaya, N, Kramarenko, M 
of passenger and freight transportations, thus reducing the time spent on movement and considering the sanitary and hygienic requirements for protection from the harmful effects of exhaust gases and noise. The choice of public transport types should be based on the technical and economic comparisons of various options depending on the size of the territory of resorts and recreational areas, value of estimated passenger flows, and seasonal fluctuations in the mobility of temporary and permanent residents [3].

\section{2 Organizational concept of the railway transportation in the coastal territories}

Ukrainian national railway, UZ, has recently presented its five-year development strategy for 2017-21. This includes the formation of five business sectors: freight transport and logistics, passenger transport, infrastructure, traction services, and manufacturing services. The 2017-21 rolling stock investment plan includes the purchase of 212 passenger locos, 35773 wagons and other. This implies that at least half of the UZ fleet would be new or modernized than the current situation in which three-quarters of the fleet is in need of modernization or replacement [18].

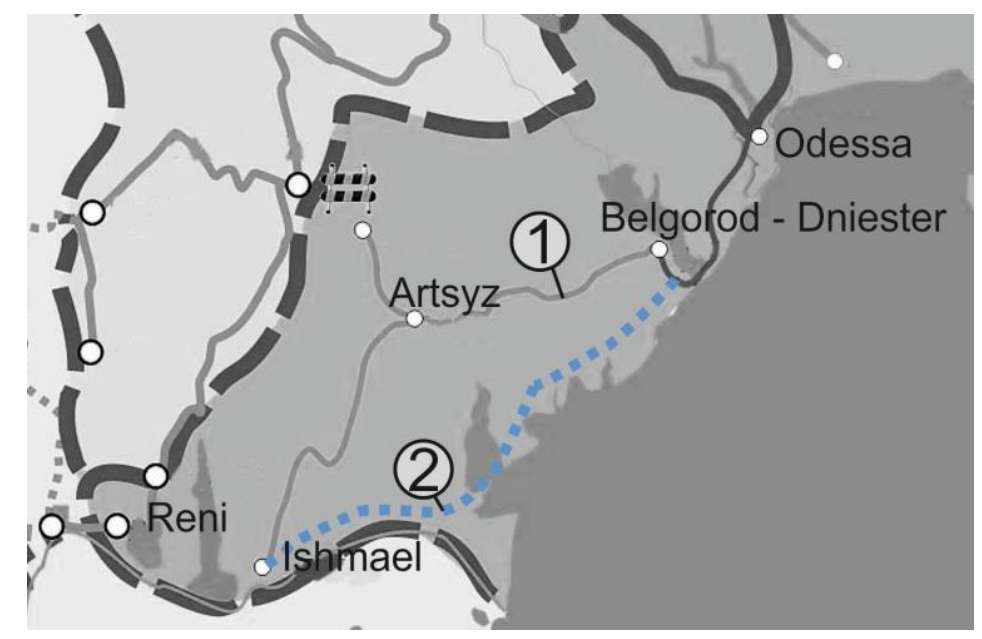

Figure 6 Organizational scheme of Sergeevka railway communite: 1) existing railway line and 2) proposed railway line along the coastline.

To solve the problem of resorts' accessibility in the south of the Odessa region, including the Sergeevka resort, it is proposed to lay a railway line from Pribrezhnyy town parallel to the coastline of the Black Sea; this does not contradict the development program of the Ukrainian railway for 2017-21 or the Drive Ukraine 2030 strategy and facilitates access to resorts and population clusters near the coastal areas (Figures 6 and 7 ).

\section{3 Reorganizational concept of the road leading to the Sergeevka resort}

The construction plan indicated for the European transport network, TEN-T, includes 39 Ukrainian infrastructure projects, which are provided in the Drive Ukraine 2030 strategy. The implementation of these 39 projects will significantly deepen the infrastructural integration of Ukraine and, in the future, become an organic part of the pan-European transport network. 


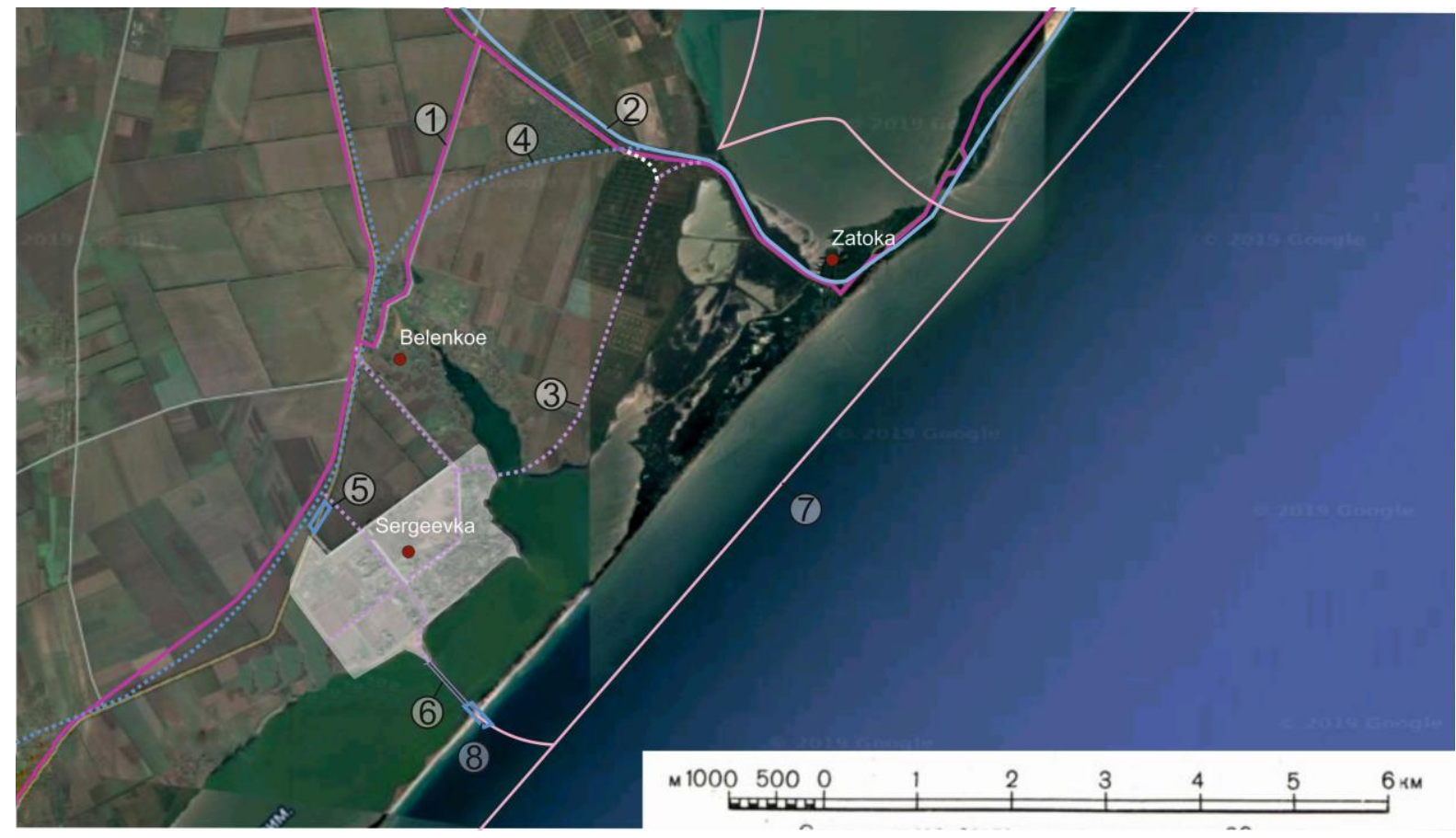

Figure 7 Organizational concept of the transport system of Sergeevka resort: 1) existing highway; 2) existing railway; 3) proposed highway; 4) proposed railway; 5) and transport hub. 6) Renewed pedestrian-transport bridge integrated into the urban transport and pedestrian scheme. 7) Renewable water-transport concept and 8) the proposed seaport with leisure facilities year-round. [20]

Moldova, and Ukraine provides the construction of $48000 \mathrm{~km}$ of roads and railways, with 6 ports and 11 logistics centers, as well as airports and boundary crossing points [19].

The interview of the residents and visiting tourists by authors in 2019 revealed dissatisfaction with the quality of the existing roads, including T1610 ( $82 \%$ of respondents agree that it is too narrow , i.e., with only two lanes, and is too far from the resort), and the desire to change its direction for greater comfort and rationality of use. The following measures were recommended.

The general plan of Sergeevka must be developed by considering the allocation of functional zones, revitalization of unfinished buildings, facilitated access to the embankment and beaches from objects and territories located not in the first rows from the estuary, and direct connection of the bridge with the city's transport scheme (upper level: with the road; lower and pedestrian level: with promenade and estuary beach).

The route of the existing highway must be modified (rerouting, straightening, and widening) as the main transport connection of the resort with the "metropolis" (Figure 7).

\subsection{Organizational concept of sea routes to the Sergeevka resort}

One of the options for improving the transport accessibility of the Sergeevka resort is the resumption of seasonal sea transport that connects the port of Odessa with resorts and settlements near the sea and estuary coast (Figure 7). In addition to the tourist and household attractiveness of small passenger-based water transport, the resumption of its work can attract investment in the revival of the shipbuilding industry. 


\section{CONCLUSION}

The following conclusions can be drawn from the results of this study:

1. The Sergeevka resort is not being used at its full potential. Significant obstacles exist in its development: for example, the absence of adequate resort development programs adopted on competitive terms, which could consider the basic needs of the town's population in the fields of education, cultural, scientific, and industrial activity, along with the development of the spa component. There still exist some unresolved problems of the resort's transport links with the "metropolis" (within the framework of the general transport problems of the metropolitan area) in terms of both variability (road, rail, and water transport) and length, route, and quality of the existing transport links [1].

2. To solve the problem of accessibility of resorts in the south of Odessa region, including Sergeevka resort, it is proposed to continue the railway branch parallel to the embankment; this would not contrast with the development program of the Ukrainian railway 2017-21 and Drive Ukraine 2030 strategy but would facilitate access for vacationers.

3. This paper proposes the development of a general plan of the Sergeevka settlement, considering the allocation of functional zones, revitalization of unfinished projects, optimization of the access to the embankment and beaches from objects and territories located not in the first rows from the estuary, and the bridge's direct connection with the city's transport scheme (upper level: with the highway; lower and pedestrian level: with the promenade and estuary beach).

4. The paper also presents the concept of reorganization and expansion of the road that leads to the Sergeevka resort as the main transport connection of the resort with Odessa city, as well as the resumption of sea transport from the port of Odessa along the southern sea coast with stops in major resorts, including Sergeevka.

\section{References}

[1] Development strategy of tourism and resorts until 2026, Available at: https://zakon.rada.gov.ua/laws/show/168-2017-\%D1\%80/sp:max100 (in Ukrainian) accessed 09 July 2020.

[2] Materials of the International Science-Practical Conference 2017: City Planning and Management of Coastal Territories, 12-13 October. smt. Sergeevka, Odessa region, Odessa, Print Bistro, p. 91 (in Ukrainian)

[3] Kaplan, L.Z., Panchenko T.F., Ionov I.I. 1976: Planning and development instructions for resorts and recreation areas. Moscow, Stroyizdat, p. 41.

[4] Panchenko, T.F. 2015: Landscape and recreation planning of natural and reservation territories, Monograph, Kiev, Logos, p. 176.

[5] Stauskas, V.P. Urban-planning organization of districts and recreation centers. Stroyizdat. Leningrad, 1977. $164 \mathrm{p}$.

[6] Belska, N.K. 2019: Prospects for the development of the resort and tourist potential of Odessa agglomeration, Abstracts of the 75th Scientific and Technical Conference of the Academy's Teaching Staff, Odessa, p. 38 (in Ukrainian)

[7] Tkachenko, V.A. 1954: The architecture of the sanatorium, Academy of Architecture of the Ukrainian SSR, Kiev, p.156.

[8] Sidorova, V.V. 2014: Principles of functional planning organization of the coastal strip of coastal resorts (taking the example of Big Alushta), thesis cand. of arch., 18.00.04. Simferopol, p. 254.

[9] Karasova, O.M. 2009: Architectural-planning organization of small hotels in the minds of natural complexes, thesis cand. of arch.,18.00.02. KNUBA, Kiev, p. 214.

[10] The Law of Ukraine "About Resorts" dated 05.10.2000, Information of the Verkhovna Rada of Ukraine, Kiev, №2026-III. Available at: http://zakon5.rada.gov.ua/laws/show/2026-14 accessed 09 July 2020.

[11] Chazov, E. I. 1983: Resorts, Encyclopedic Dictionary - Moscow, Soviet Encyclopedia, p. 20.

[12] Sergeevka - Rest, recovery and heritage of the union, Available at: https://rent.ua/kurortiukraini/sergeevkaotdih-ozdorovlenie-i-nasledie-sojuza (in Russian) Accessed 09 July 2020.

[13] Horizon Health Resort, Available at: https://www.pivdenks.com/orizont (in Russian) Accessed 09 October 2019.

[14] Kramarenko, M. O. 2018: The scientific principles of architectural and planning organization of health resort hotels, thesis cand. of arch., 18.00.02. KNUBA, Kyiv, p. 20. 
[15] Available at: http://www.etomesto.ru/map-ukraine_odessa_genshtab-500/ (in Russian) Accessed 02 January 2020.

[16] Available at:

https://newmap.land.gov.ua/?cc=3383618.821842825,5786235.268045162\&z=13\&l=\&bl=dzk_overview (in Ukrainian) Accessed 02 January 2020.

[17] Climatic and balneal mud Sergeevka resort, Available at: http://odesskiy.com/otdih-vodesse/klimatobalneogrjazevoj-kurort-sergeevka.html (in Russian) accessed 09 July 2020.

[18] Ukrainian Railways plans five-year investment program, 2019 DVV Media international LTD, Available at: https://www.railwaygazette.com/NEWS/POLICY/SINGLE-VIEW/VIEW/UKRAINIAN-RAILWAYS-PLANSFIVE-YEAR-INVESTMENT-PROGRAMME.HTML Accessed 09 July 2020.

[19] Available at: http://www.dsnews.ua/economics/evrokomissiya-vydelit-4-5-mlrd-evro-dlya-integratsii-ukrainy18012019183000 Accessed 09 July 2020.

[20] Available at:

https://www.google.com.ua/maps/place/\%D0\%A1\%D0\%B5\%D1\%80\%D0\%B3\%D0\%B5\%D0\%B5\%D0\%B2 \%D0\%BA\%D0\%B0 Accessed 02 January 2020.

Please cite this article as: Belskaya, N., Kramarenko, M: Urban planning perspectives of the potential of resort development in the Sergeevka settlement with traffic improvement, Electronic Journal of the Faculty of Civil Engineering Osijek-e-GFOS, 2020, 20, pp. 63-72, https://doi.org/10.13167/2020.20.6 